\title{
A Regulatory Framework Assessment on Multispecies Urban Planning in Indonesia A Case Study of Two Indonesian Cities in Java and Borneo
}

Rukuh Setiadi ( $\square$ rukuh.setiadi@pwk.undip.ac.id)

Universitas Diponegoro https://orcid.org/0000-0003-3419-2584

Salma Zulfa Nadhiroh

Universitas Diponegoro

Christoph Rupprecht

Ehime University

\section{Research Article}

Keywords: multispecies, urban planning, regulatory framework, spatial plan, Indonesian cities

Posted Date: July 30th, 2021

DOI: https://doi.org/10.21203/rs.3.rs-715509/v1

License: (c) (i) This work is licensed under a Creative Commons Attribution 4.0 International License.

Read Full License 


\section{Abstract}

Despite benefits for human civilization, urbanization has brought an enormous consequence to nonhuman species. Multispecies planning is a potential solution in response to increasingly insensitive urban planning to non-human species. This paper aims to understand the link between a national regulatory framework and its outcome in terms of urban spatial plan from multispecies planning point of view using indicators such as from protected forest to natural reserve and from ecological corridors to private yards. It examines whether the existing regulatory framework is an obstacle to the practice and implementation of multispecies planning ideas in a city. We employ a content analysis to assess 18 laws and policies at the national level. We also utilize a case study to test the spatial plan outcome in two areas in Indonesia, namely the city of Semarang (Central Java) and Barito Utara Regency (Central Borneo), in which also involve additional content analysis of 4 local regulations accordingly. The study successfully maps out the extent of relative emphasis of each multispecies urban planning indicators according to Indonesian national regulatory frameworks. The study also reveals that regulatory frameworks at the national level do not really determine multispecies urban planning practices at the local level, nor does the status of biodiversity assets owned by a city or region. Improving the literacy of planners, planning committee, and other key decision makers in multispecies planning is pivotal and warrants a further investigation.

\section{Introduction}

Planning always affects more than the human species, a fact that is recognized through key principles in SDGs, especially Goal 14 and 15 (life on earth and below water). In line with the SDGs, the New Urban Agenda mandates protection of ecosystems and biodiversity including adopting a life integrated with nature (United Nations, 2017). Currently, more than half of the global population live in cities (UNDESA, 2018), but various other species share these same areas (Anderson et al., 2020). The era of 'planetary urbanization' thus presents challenges to sustainability and justice that extend beyond humans to all forms of life. As built up and protected areas are increasingly in close proximity due to worldwide urbanization (Borgström et al, 2013:66), nature conservation in human dominated landscapes is urgent and critical.

Theory and practice of urban planning have been explicitly aimed at and preoccupied with benefiting humans. Houston et al (2017) indicate that the assumptions built in planning practice, for example, only accommodate human values and perspectives. Non-human species such as flora and fauna in urban areas are routinely marginalized. Regulatory and policy frameworks, particularly those related to urban spatial planning, may be critical elements and act as a key drivers that could explain this tendency. But as Houston and colleagues suggest, a different kind of planning ought to be possible. This paper aims to challenge the status quo by asking a fundamental question regarding a different, 'multispecies' planning in the context of the developing world: is the national regulatory framework an obstacle to the practice and implementation of multispecies planning ideas in a city? We further extend our analysis through our second research question: to what extent do planning documents produced by planners at the city level incorporate aspects of multispecies planning? These two questions are pressing, considering widely 
critized yet ongoing commodification of the urban environment through a process of urbanization that separates human life from the wild (Wolch, 2002; Byrne and Wolch, 2009; Steele, Wiesel, \& Maller, 2019), including in Indonesia (Subekti, 2012; Afif et al, 2014; Suwarso et al, 2019).

To address these questions, we draw upon previous research (Byrne et al, 2009; van Dooren and Rose, 2012; Houston et al, 2017; Parris et al, 2018; Rupprecht, 2017; Steel et al, 2019) to define multispecies planning in this context as efforts in spatial allocation giving substantial and equitable attention to various forms of life or species in a city or urban setting. The term multispecies here takes inspiration from a school of thought emerging across humanities and social sciences that acknowledges more-thanhuman agency in co-shaping spaces, including cities (Ogden et al, 2013). Crucial to this mode of scholarship is its endeavour to cultivate attentiveness (van Dooren et al, 2016) to linkages, entanglements and intersections between humans as well as their institutions and the diversity of life, its components, processes and interactions. Plumwood (2009) states that taking into account of multispecies in urban planning can be done through building connectivity in the form of regulations related to planning. In other words, whether the various criticisms of the failure of urban planning to integrate a multispecies perspective can be attributed to the weakness of the regulatory framework provides an interesting angle for examination.

We take up this task in this paper by first identifying indicators for implementing multispecies planning based on a literature review. Next, we identify the various regulatory frameworks that apply in Indonesia. We then use a qualitative method by applying content analysis to answer our research questions. The content analysis method is directed by identifying the important elements in multispecies planning that are contained in various regulatory and policy frameworks in Indonesia. Finally, we compare the results of the content analysis in two different case studies to see the effect of regulations at the operational level.

\section{Multispecies Urban Planning: An Emerging Theme}

Multispecies planning is one of the themes emerging from the wider field of multispecies studies. Houston and colleagues (2018) signal the importance of revisiting the involvement of humans and other species in planning theory. Historically, humans have depended on interacting with biodiverse life forms of their surroundings in order to thrive. Although urban settlements have long been discovered, the original ecology has been proven exist in the historical studies of vegetation before urban settlements emerged (Anderson et al., 2020).

Biodiversity and the stability of these ecosystems provide natural resources and thereby supported community life that generally existed in agricultural societies until the 19th century. However, a tremendous shifting of urban socio-economic culture leading to rapid urbanization is changing this interaction. This is expected to have an enormous impact in the future, as Adams (2005) argues that urbanization in the future can change, divide and isolate wildlife habitats, especially in urban areas. Recent studies have also indicated that habitat disconnectivity increases with land use change (Almenar et al, 2019), while Kowarik (2011) comprehensively examines the biotic response to urbanization. Several 
species have adapted and occupied urban environments and coexist with human activities (Bateman \& Fleming, 2012).

The human-nature interaction remains important to be maintained, not only because of the intrinsic value possessed by nature, but also as a foundation for the sustainability of urban life while giving respect for the values of inter-species justice. Wolch (2002) indicates the importance of human-animal relations in urban areas to coexist and design cities as a place for both humans and animals. Along with the pressure of urbanization, Kowarik (2011) suggests that conservation approaches should consider the perspective of novel urban ecosystems as argues that cities may be rich in both native and non-native species, though urban habitats cannot replace the functionality of natural remnants. On top of it, whatever the context is, humans living in urban areas will still have the same dependence on nature as before.

Multispecies planning is an idea arising from the concern that urban planning is increasingly insensitive to non-human species. In other words, it focuses only on the human domain which is built on the nature (Wolch, 2002). Such a plan has failed in seeing humans and non-human species in forming a relationship in the urban environment (Byrne and Wolch, 2009). As a consequence of this unbalanced relationship is from the decline to the extinction of species that inhabit cities.

\section{The Articulation of Multispecies Planning}

Multispecies urban planning is not something entirely new. Planners, architects and engineers do not need a separate 'conceptual leap' in describing urban conservation ideas to enhance biodiversity because these efforts have been around for a long time, such as ecological sensitive principles, the creation of urban parks, the idea of regional planning, and the concept of design with nature (Paris et al, 2018: 44), and recently Bush and Doyon (2019) frames as nature-based solutions for resilience urban planning. However, we argue that multispecies planning embraces a stronger eco-centric view than the other concepts. By using a metaphor to bridge the language of ecologists and urban planners, Parris, et al (2018) have succeeded in providing seven basic principles for biodiversity planning in cities.

First, identify and protect areas with high biodiversity. These areas can be in the form of natural forests that contain the habitats of wildlife, which are generally outside the administrative boundaries of the city. These areas are formally designated as a national park, nature reserve or protected forest.

Second, maintaining connectivity between habitats to provide space for animal and natural process connectivity. Adult animals such as birds need space for daily or seasonal migrations, foraging for uneven distribution of food, forming colonies and creating territories. Meanwhile, natural processes such as spreading of fungi, seeds, spores and pollination which as the foundation for landscape diversity will also occur if there is connectivity. In the context of spatial planning, this principle can be realized, for example by means of an ecological corridor (Almenar et al., 2019; van Dooren \& Rose, 2012). Connectivity in physical form can be demonstrated by building bridges for wildlife on roads that can reduce the risk of accidents for animals as well as humans. 
Third, the creation of ecological features as habitats for various types of animals and plants. In this context, multispecies can be introduced in the form of botanical gardens and parks within the city (Hartigan, 2015). Hartigan (2015) promotes the creation of public spaces which are not only as gardens and plants that will be used by humans, but also a mixture of human and non-human species elements in the same space. Hartigan (2015) theorizes multispecies publics as 'distinctive cultural assemblages that distinctly align humans and nonhumans in relations of care' (p. 481). The development of urban forests, city parks, analogous habitats such as vertical and roof top gardens, and private yards are manifestations of this principle. Making artificial lagoons and ponds can also be categorized as this effort.

Fourth, maintaining the water cycle, energy and nutrients that are essential for the provision of ecosystem services. These cycles are very real and are seen in cities. Without a cycle, biodiversity will collapse. Water, for example, is a source of life for all living things, and even becomes a habitat for a number of species. Water bodies in cities, such as rivers, swamps and lakes, are important to be conserved and integrated as an important component in spatial plan. Urban plan should guarantee this cycle to be maintained. A healthy water cycle does not only provide benefits for non-human species, but also for the survival of humans, preventing flooding in the rainy season and drought during the dry season.

Fifth, the maintenance of biological networks, especially symbiosis, predation, pollination, and parasitism, which are needed to establish the biodiversity in an area. The reduction of bee species which are important for pollination, for example in the City of Curitiba, Brazil (Cardoso \& Gonçalves, 2018) indicates the effect of urbanization that is not multispecies perspective. As another example, the decreasing population of birds as the main predators has led to increased crop pests in urban areas.

Sixth, minimizing various forms of physical and infrastructure development that have a negative impact on biodiversity because it increases species mortality. For example, the construction of roads that passthrough wildlife home range areas will increase the risk of road accidents, not only for animals but also for humans. In lowa, 13\% of reported accidents were between vehicles and deer (Gkritza et al., 2014). Birds often crash into the windows of high-rise buildings in cities as it is difficult for them to detect. Cities can also be a source of disease in animals (Soulsbury \& White, 2015), such as Toxoplasma gondii and Sarcocystis neurona from city sewage runoff infected sea otters in California (Shapiro, Miller, \& Mazet, 2012).

Finally, maintaining novel ecological communities where native and exotic species can coexist as it has never seen before. This indicates that the area is a healthy area where the food requirements of the associated species are available. Apart from appearing urban forests or parks, novel ecological communities, may also appear in urban informal spaces such as vacant lands, abandoned areas (former industrial areas), railway corridors, and others (Rupprecht, 2017).

In addition to spatial or landscape-based principles that are in the planning domain, there are also a number of principles in the domain of spatial utilization and control. Poessel et al (2017) and Hartigan (2015) for example convey the need for education and development of programs to urban community so 
that they become familiar to flora and can develop relationships between multispecies. Meanwhile, Messmer (2020) indicates the importance of wildlife management to minimize the emergence of conflict between humans and wildlife in urban areas, through: (i) protection and preservation of wildlife and their habitats accompanied by protection of individual communities; (ii) increasing the role of stakeholders in determining conflict management policies between humans and wildlife; (iii) development of information and additional data to solve problems between humans and non-human species; and (iv) increasing community tolerance to wildlife, one of which is by providing information about the benefits of wildlife to the community. Table 1 summarize domain, principles, and indicators for multispecies urban planning.

Table 1

Domain, Principles, and Indicators for Multispecies Urban Planning

\begin{tabular}{|c|c|c|}
\hline Domain & Principles* & Indicators \\
\hline \multirow[t]{12}{*}{ Planning } & \multirow[t]{3}{*}{ Protection } & Protected forest \\
\hline & & National park \\
\hline & & Natural reserve \\
\hline & \multirow[t]{2}{*}{ Connectivity } & Ecological corridor \\
\hline & & Riverbank, Greenbelt \\
\hline & \multirow[t]{5}{*}{ Construction } & Botanic garden \\
\hline & & Urban forest \\
\hline & & Urban park \\
\hline & & Analog habitat \\
\hline & & Private yard \\
\hline & \multirow[t]{2}{*}{ Novelty } & Vacant land \\
\hline & & Abandon area \\
\hline \multirow[t]{2}{*}{ Utilization \& control } & Management & Urban wildlife management \\
\hline & Education/Campaign & Wildlife/ species education \\
\hline
\end{tabular}

\section{Area of Debate on Multispecies Urban Planning}


In this section, we offer two area of debate on multispecies urban planning. First, interactions between humans and non-human species, especially wildlife, in some cases have unexpected impacts. Direct attacks on humans by wildlife are possible (Soulsbury \& White, 2015), although attacks by wildlife that cause injury and death are relatively rare (Mayer, 2013). Poessel at al (2016) highlights the presence of Coyote in urban areas in the US, and states that in addition to its adaptability, the presence of Coyotes and conflicts with humans in urban areas is correlated with the size of the city and its density. It is similar to the case of tiger sighting to prey domestic livestock in Indian human settlement (Karanth \& Surendhra, 2018) and other human-wildlife conflicts found in Negeria (Magama et al, 2018). However, this generally starts from the anthropogenic destruction of habitats and ecosystems that causes them to penetrate and enter human habitats. Apart from being an attack, the presence of species can also create disturbance and economic loss through property damage (Soulsbury \& White, 2015).

Another risk that comes with multispecies urban planning is disease transmission (Bengis et al., 2004), such as a case study in Switzerland where foxes spread Echinococcus disease to humans (Fischer et al., 2005); case study of bat spillover in Queensland in the 1990s (Smith and Wang, 2013; Mendez et al, 2012) and in Democratic Republic of Congo (Leroy et al, 2009). It also includes the case of palm civets as intermediary of Severe Acute Respiratory Syndrome (SARS) in China and Hongkong (WHO, 2003), while chimpanzees and monkey are closely associated to the origin of HIV-2 spread in Africa (Lemey et al, 2003; Sharp et al, 2000).

Second, efforts to link urban habitats are considered less significant when optimization between landscape typology and species to be protected is taken into account. Forested areas get priority over urban areas (Clauzel, Jeliazkov, \& Mimet, 2018). However, efforts to presenting biodiversity in urban areas should not always be measured by optimization. Multispecies urban planning is important to improve the quality of life for the multispecies itself (van Dooren \& Rose, 2012), but it can also provide co-benefits to human.

As a biotic component, plants or trees for example have various benefits for humans and other species. Trees in cities show a significant influence on the quality of urban biodiversity (Schmidt, Poppendieck, \& Jensen, 2014). Trees are a necessity for various types of fauna for nesting sites, food storage and food sources themselves (LaMontagne et al., 2014). Trees in cities have broader benefits, such as being a micro-climate stabilizer (Aminipouri et al., 2019; Wang \& Zacharias, 2015) and shading from trees creates a feeling of comfort for pedestrians in urban areas, especially in summer or in tropical cities (Wang \& Akbari, 2016). Abundan vegetation in cities can play a role in mitigating air pollution (Cavanagh, Cohen, \& Allen, 2009). The existence of trees in cities also has a direct impact on the economic value of a property, as happened in Portland, Oregon (McDonald, 2015). A study suggests that biodiverse environmental microbiomes contribute positively to human health and could account for known associations between urban green space and improved health (Flies et al, 2018).

\section{Policy, Regulation and Multispecies}


There has not been a specific research that address the link between policy, regulation and its outcome in terms of multispecies-sensitive urban spatial plan. A similar idea of research scrutinizing policy and regulation previously focused on environmental service (Rall et al, 2015) in New York and Berlin; naturebased solutions (Zwierzchowska et al, 2019) in Poznań.

Hardion et al (2015) study shows that multispecies perspective is also absence in the case of town of Frejus, Mediteranean France where the local authority overlooked the existence of a legally protected endemic reed, Arundo donaciformis (Poaceae) in their urban plan, which basically plays important role to provide ecological services associated with riverbank stabilization and natural corridors between peripheral natural areas and urban green spaces. Olive and Minichiello (2013) examine the governance around conservation in five largest cities of the US to understand the contribution of US Fish and Wildlife Service and cities with regard to 1973 Endangered Species Act. Despite good intention of the law, there is lack of action from these city authorities to protect almost 80 listed endangered species within their administrative territory. In contrast, Rodríguez-Rodríguez and Martínez-Vega (2018) study shows the effectiveness of various type of protected areas against land development in Spain.

Best practices of multispecies urban planning exist in a number of cities, such as in the City of Austin in Texas and Atlanta in Georgia (Vecchio, Marzluf, \& Fitzgerald, 2019). The Austin City Government has incorporated wildlife conservation into a comprehensive plan and planning process that supports the existence of wildlife and promoted habitat gardening, a movement providing gardens dedicated to develop natural habitats so that attract wildlife and birds in home, work and school environments. In addition, habitat gardening is also integrated to wildlife educational programs and teaching in schools. Meanwhile, the City of Atlanta known as 'the city in a forest' has preserved their old gigantic-scale urban trees as one of the city's planning goals, which is to restore tree canopy in urban areas to support wildlife and communities (Atlanta City Government, 2015). The city government is also aggressive in conducting urban ecological studies and inventory of the natural environment in urban areas to provide future recommendations for better human-nature connectivity and green policies. It also informs the design of the City of Atlanta and the formulation of a tree protection law (Atlanta City Government, 2020).

Sweden is also a great example in this context. An evaluative study on one century of nature conservation in the country (Borgström et al, 2013:66) shows that 'the objectives 'outdoor recreation' and 'species biodiversity preservation' were more common in urban reserves, while preservation of habitats were more common in rural". However, from the last decades they found indications of a shift in use of objectives in urban areas, going from outdoor recreation to a stronger focus on species diversity conservation.

The challenge for multispecies planning lays in understanding the intersecting human-wildlife, the relationship between community and ecology, and justice in multispecies landscapes including how to accommodate non-human species in urban areas (Hunold \& Lloro, 2019). The existence of non-human species in urban areas, either directly or indirectly, also has a positive impact on humans, but also has several negative impacts. Therefore, non-human species is one of the elements that must be considered 
by decision makers to establish a regulatory and policy framework. Failure in understanding and integrating these two 'interconnected worlds' (e.g. human and wildlife) in urban planning and management brings negative consequences to both sides.

\section{Data And Methods}

This study examines the various regulatory frameworks that apply in Indonesia. We divide the regulatory frameworks into two categories: (i) regulations related to urban spatial and development plans and (ii) sectoral regulations outside the spatial planning domain. In the first category, the urban spatial plan regulatory framework refers to Law 26/2007 on Spatial Planning and its derivatives, while the regulatory framework regarding development plan refers to Law 25/2004 on the National Development Planning System and Law 23/2014 on Regional Government and their derivatives. The derivative regulatory framework from the first category includes local regulations regarding the Urban Spatial Plan (RTRW) and the Regional Medium-Term Development Plan (RPJMD) of the study area.

Meanwhile, the second category, sectoral or thematic regulatory frameworks outside the spatial planning domain are laws and regulations related to the environment, conservation of biodiversity and ecosystems, waters, and forestry. Table 2 presents the list of regulations included in the analysis.

Table 2

\section{List of Analyzed Regulatory Frameworks}

\section{Regulatory Frameworks}

$\begin{array}{lll}\text { Scale } & \text { Spatial and Development Plan } & \text { Sector/Thematic } \\ \text { National } & \text { - Law 26/2007 on spatial plan } & \text { - Law 32/2009 on the protection and } \\ \text { - Law 25/2004 on development } & \text { management of the environment } \\ \text { planning system } & \text { - Law 5/1990 on Biodiversity and ecosystem } \\ \text { - Law 23/2014 on local governance } & \text { conservation } \\ \text { - Government Regulation 13/2017 } & \text { - Law 17/2019 on water resource } \\ \text { on national spatial plan } & \text { - Law 27/2007 on the management of coastal } \\ \text { - Government Regulation 15/2010 } & \text { and small islands } \\ \text { on arrangement of spatial planning } & \text { - Law 37/2004 on land and water conservation } \\ \text { - Government Regulation 3/2012 on } & \text { - Law 41/1999 on forestry } \\ \text { spatial plan of Kalimantan Island } & \text { - Government Regulation 28/2011 on the } \\ \text { - President Decree 28/2012 on } & \text { management of natural conservation and natural } \\ \text { spatial plan of Java and Bali Islands } & \text { reserve areas } \\ \text { - President Decree 18/2020 on } & \text { - Government Regulation 38/2011 on river } \\ \text { national mid-term development plan } & \text { - Government Regulation 37/2010 on dam } \\ \text { 2020-2024 } & \text { - Government Regulation 63/2002 on urban } \\ & \text { forest }\end{array}$

\section{Study Area}


This study selects Semarang City and Barito Utara Regency as a case study example because both regions have different conditions. Semarang City represents a metropolitan city with a more intense level of urbanization so that the pressure on non-human species is relatively higher than that of Barito Utara Regency. As the capital city of Central Java, Semarang has a population density of 4,780 people per square kilometer and an average population growth rate of $1.44 \%$ per year. In the midst of high urbanization, Semarang still has several locations that are maintained for the continuity of non-human species, even though their biodiversity is relatively low as in the studies of Subekti (2012) and Afif et al (2014) on urban forests and mangrove ecosystems respectively. Suwarso et al (2019) stated that there was a sharp decline in the number of urban wildlife as a result of city development activities.

Meanwhile, the Barito Utara Regency in Central Kalimantan, with the main urban area namely Muara Taweh, represents a region with higher diversity with a lower level of urbanization. Barito Utara Regency has a population density of 18 people per square kilometer. Having a high level of biodiversity, Barito Utara Regency establish several wildlife protection areas in the form of nature reserves and protected forests. In addition, there is also the Heart of Borneo, which is an internationally agreed protected area as forest on the island of Borneo, which provides life for about $40 \%$ of the world's flora and fauna species. Therefore, it is interesting to see whether this contrasting condition affects the urban planning themes in these two regions and used to answer proposed research questions. Figure 1 shows the orientation of study areas in Indonesia.

\section{Result}

An analysis of the regulatory frameworks in Indonesia shows that most policy and regulations at the national level have integrated multispecies, although the word multispecies is not explicitly stated. Table 3 presents the components which already governed by the Indonesian sectoral and spatial planning regulatory frameworks. In general, multispecies planning indicators are more integrated in sectoral regulatory framework than in spatial planning and development regulatory frameworks. 8 out of 10 sectoral laws and regulations covers almost all multispecies indicators, while it is only 6 out of 8 spatial planning and development system laws and regulations that cover multispecies indicators.

\section{Table 3}

\section{Multispecies Related Indicators Regulated in the Sectoral and Spatial Planning Regulatory Frameworks in Indonesia.}


Spatial Planning \&

Development

$(\mathrm{Y} / \mathrm{N}) \quad$ Numbers of

Laws/Regs. Articles
$(\mathrm{Y} / \mathrm{N}) \quad$ Numbers of

Laws/ Articles Regs.
Total Number

Laws/ Articles Regs.

\section{Planning}

\begin{tabular}{lcccccccc|} 
Forest & $\mathrm{Y}$ & 6 & 9 & $\mathrm{Y}$ & 2 & 6 & 8 & 15 \\
National park & $\mathrm{Y}$ & 4 & 5 & $\mathrm{Y}$ & 3 & 3 & 7 & 8 \\
$\begin{array}{l}\text { Natural } \\
\text { reserves }\end{array}$ & $\mathrm{Y}$ & 4 & 5 & $\mathrm{Y}$ & 3 & 3 & 7 & 8 \\
$\begin{array}{l}\text { Ecology } \\
\text { corridor }\end{array}$ & $\mathrm{Y}$ & 1 & 2 & $\mathrm{Y}$ & 1 & 1 & 2 & 3
\end{tabular}

$\begin{array}{|lllllllll|}\text { Green barriers } & \mathrm{Y} & 4 & 4 & \mathrm{Y} & 2 & 4 & 6 & 8 \\ \begin{array}{l}\text { Botanical } \\ \text { garden }\end{array} & \mathrm{Y} & 4 & 5 & \mathrm{Y} & 2 & 2 & 6 & 7\end{array}$

\begin{tabular}{lllllllll} 
Urban forest & $\mathrm{N}$ & 0 & 0 & $\mathrm{Y}$ & 1 & 2 & 1 & 2 \\
\hline Urban park & $\mathrm{Y}$ & 1 & 1 & $\mathrm{~N}$ & 0 & 0 & 1 & 1 \\
\hline Analog Habitat & $\mathrm{N}$ & 0 & 0 & $\mathrm{~N}$ & 0 & 0 & 0 & 0 \\
\hline Private yard & $\mathrm{Y}$ & 1 & 1 & $\mathrm{~N}$ & 0 & 0 & 1 & 1 \\
Vacant land & $\mathrm{N}$ & 0 & 0 & $\mathrm{~N}$ & 0 & 0 & 0 & 0 \\
Abandon areas & $\mathrm{Y}$ & 1 & 1 & $\mathrm{~N}$ & 0 & 0 & 1 & 1
\end{tabular}

\section{Utilization and}

\section{Control}

$\begin{array}{lcccccccc}\begin{array}{l}\text { Urban Wildlife } \\ \text { Management }\end{array} & \mathrm{N} & 0 & 0 & \mathrm{~N} & 0 & 0 & 0 & 0 \\ \begin{array}{l}\text { Wildlife/ } \\ \begin{array}{l}\text { species } \\ \text { education }\end{array}\end{array} & \mathrm{N} & 0 & 0 & \mathrm{Y} & 1 & 1 & 1 & 1 \\ & & & & & & & \end{array}$

Note: $Y=Y e s ; N=$ No 
Of the 14 indicators for implementing multispecies urban planning, 11 of them have been indicated in various laws and regulations. Three types of indicators that are not found at all in the national regulatory frameworks are: (i) vacant land; (ii) analog habitat (such as vertical garden, rooftop garden), and (iii) the management of urban wildlife. This indicates that there is a regulatory gap on these three indicators. Considering the quantity of the laws and regulations, Fig. 2 maps out a multispecies-related national regulatory framework to show the extent of relative emphasis of each indicator in Indonesian context.

Vacant land, analog habitat and urban wildlife management are least regulated aspect. Ideally, species that are living on vacant land in urban areas needs to be acknowledged in planning. Important species in this piece of landscape needs to be integrated, especially when the land is going to be cultivated or will be developed. Initial data on the presence of species on any vacant land in the city need to be documented by the environmental office. It is instrumental for urban planners, developers and engineers to deliver multispecies-sensitive planning and design. It also helpful in the process of environmental impacts assessment of project within and near by the land. Meanwhile, analog habitats such as vertical and roof top gardens also need to be promoted and can be integrated as requirements for development permits. Vertical and rooftops gardens can be used as a building code element, especially in areas where conventional provision green open space does not feasible technically.

Urban wildlife management does not yet exist in the national regulatory framework because urban multispecies planning discourse itself has not explicitly emerged. Urban wildlife management is still limited to prohibit hunting of species, which is specifically aimed at endangered species in the conservation areas, but not in cities. Moreover, urban wildlife management as a mitigative response to urban development activities has not been integrated into urban-wide planning. The component of urban wildlife management should be part of a strategic environmental recommendation in urban development plans.

Spatial plan and sectoral regulatory frameworks differ in concerning multispecies. Indicators which are closely related to 'space for multispecies' are more dominantly discussed in the spatial planning regulatory framework. This cannot be separated from the function of spatial planning which regulates space allocation in a given area. As a result, the form of integration strategies of non-human species in urban area is more diverse in the planning regulatory framework. The spatial planning regulatory framework determines the locations, criteria, strategies, policies, and management of wildlife and essential ecological process in urban and regional context. Meanwhile, the sectoral regulatory framework predominantly regulates 'protection, conservation and utilization functions.' It provides a focus on nonspatial strategies for multispecies. The sectoral regulatory framework discusses the types or classifications of conservation areas, conservation functions, and provisions for the protection of designated conservation areas.

Protected forest, national parks, and natural reserves are the top three indicators that most regulations talk about. A significant number of articles in the laws and regulations discuss these multispecies indicators in comparison to other indicators. In Indonesian context, with large geographical areas, most 
of these spatial categories belong to rural or remote areas instead of urban, where they are away from urban growth. Green barriers (e.g. in riverbanks, ponds, springs, road side, railways) and botanical garden are the next group of indicators that is also highly regulated.

However, other indicators of multispecies urban planning, such as ecological corridor, urban forest, urban park, private yard, abandon area, and education of urban wildlife do not receive attention in Indonesian regulation frameworks. In exception to ecological corridor, for example, they are mentioned in only one regulation and in a single article each. The urgency of education on wildlife is underlined by Law No. 5 of 1990 on Conservation of Biodiversity and Ecosystems. Meanwhile, from the planning regulation framework point of view, there is no article that directs the wildlife education indicator to become one of the key instruments in the urban plan utilization and control. Next, we take a deeper look at and compare the regulatory framework at the local level.

Comparison of Development and Spatial Plans at the Local Level

Table 4 compares the statutory documents of regional development and spatial plans in Semarang City and Barito Utara Regency against 14 multispecies urban planning indicators.

Conservation is an important element for protection in the context of multispecies. Articles in the spatial plan regulation in two study areas underscore conservation in general. it is in Article 6 to Semarang City, while it is in Article 5 to Barito Utara Regency. In Semarang, two conservation policies related to multispecies planning include increasing the management of areas that function as protection and providing proportional green open space throughout the city. These two policies are further elaborated with three main strategies, namely: (i) gradually restoring and regulating land tenure in accordance with the protection function designation for the government; (ii) increasing the conservation value of protected areas; and (iii) designating an area with a slope of more than $40 \%$ as a protected area. Meanwhile, the Barito Utara spatial plan policy regarding multispecies is not too specific, which it mentions that 'local government strives to balance development and forest conservation (Article 5, point 2). Indeed, local regulation for spatial in Barito Utara is not as detail as those in Semarang. While the local regulation on spatial plan in Semarang cover 189 pages, it is only 101 pages for Barito Utara. In Semarang the allocation of space to operationalize conservation policies and multispecies appears in 11 articles, while in Barito Utara it only appears in 5 articles.

In the spatial plan of Semarang, the protected area includes six categories namely: water catchment, locally protected areas, green open space, natural reserve, preservation area, and hazard prone area. Water catchment refers to the area with slope more than $40 \%$ (Article 59), while locally protected area refers to green barriers (Article 60) which includes greenbelt of the coast (Article 61), rivers (Article 62), dams and ponds (Article 63). Green open space (Article 64) is associated to urban parks, green areas along street corridors, high electricity transmission corridors, railways, graveyards, and industrial forest plantation area (article 79). 
The notion of private green open space is also introduced by Semarang spatial plan. It includes green space in the industrial estate, mandatory green area in real estate, business, and commercial complexes (Article 66) which could implement a roof top garden (Article 65) and inherent with a building coverage permit.

The idea of protected forest, national park and natural reserves do not exist in Semarang spatial plan. Semarang spatial plan claims to allocate natural reserves which basically refer to urban forests (Article 67) which allocated in Kreo and Tinjomoyo (Article 68), mangrove area (Article 70), and species refugee area particularly for local birds and monkey in Srondol, Sadeng, and Pudak Payung (Article 71).

Meanwhile in the spatial plan of Barito Utara, the protected area also includes six categories namely: protected forests, water catchment, locally protected areas, aquatic area, conservation area, and natural hazard prone area. Allocation for protected forests is in Lahei and Gunung Purei Districts with approximately 39,596 hectares (Article 19). It also serves as a customary forest of the local native tribe. The plan claims approximately 837,000 hectares of water catchment distributed over 9 districts (Article 20 ) and it tends to overlap with other categories or functions. Locally protected area in Barito Utara also refers to the 6 main rivers and tributaries flowing in the region (Article 21) and green barriers along these rivers, lakes and ponds (Article 22). As a less urbanized region in the heart of Borneo, Barito Utara allocates almost 6000 hectares of natural reserve namely Parawen I and Parawen II in Teweh Tengah District. Table 4 provides a detailed comparison of the spatial plans in the two case studies from multispecies urban planning point of view. 
Table 4

A Detailed Comparison of the Spatial and Development Plans in Semarang and Barito Utara

\begin{tabular}{|c|c|c|c|c|}
\hline \multirow{4}{*}{$\begin{array}{l}\text { Parameters and } \\
\text { Indicators }\end{array}$} & \multicolumn{4}{|c|}{ Regulation Frameworks } \\
\hline & \multicolumn{2}{|l|}{ Spatial Plan } & \multicolumn{2}{|c|}{ Development Plan } \\
\hline & Semarang & $\begin{array}{l}\text { Barito } \\
\text { Utara }\end{array}$ & Semarang & Barito Utara \\
\hline & $\begin{array}{l}\text { Local Reg. } \\
\text { 14/2011 }\end{array}$ & $\begin{array}{l}\text { Local Reg. } \\
3 / 2019\end{array}$ & $\begin{array}{l}\text { Local Reg. } \\
11 / 2017\end{array}$ & Local Reg. 1/2019 \\
\hline \multicolumn{5}{|l|}{ Planning } \\
\hline $\begin{array}{l}\text { (Protected) } \\
\text { forest }\end{array}$ & & Articles 19, & & $\begin{array}{l}\text { Prevention and management } \\
\text { of forest fire }\end{array}$ \\
\hline National park & & Article 36* & & \\
\hline Natural reserves & & Articles 23 & & \\
\hline \multicolumn{5}{|l|}{ Ecology corridor } \\
\hline Green barriers & $\begin{array}{l}\text { Articles } \\
60-63 \\
\text { Article } 66 \\
\text { Article } 70\end{array}$ & $\begin{array}{l}\text { Article 21, } \\
22\end{array}$ & & $\begin{array}{l}\text { Replantation on the riverbank, } \\
\text { lake, and spring }\end{array}$ \\
\hline
\end{tabular}

Botanical garden

Urban forest Article 67

Article 68

Urban park Articles

Management of Management of green space

$64-66$

green space

Habitat Analog Articles 65

Private yard Articles

$64-66$

Vacant land

Abandon areas

Utilization \&

Control

Urban Wildlife Articles 67

management Articles

$71^{\star \star}$

Note: *) idea to enhance legal status of forest from protected forest to national park. **) species refugee zone and mangrove area 


\begin{tabular}{|c|c|c|c|c|}
\hline \multirow{4}{*}{$\begin{array}{l}\text { Parameters and } \\
\text { Indicators }\end{array}$} & \multicolumn{4}{|c|}{ Regulation Frameworks } \\
\hline & \multicolumn{2}{|c|}{ Spatial Plan } & \multicolumn{2}{|c|}{ Development Plan } \\
\hline & Semarang & $\begin{array}{l}\text { Barito } \\
\text { Utara }\end{array}$ & Semarang & Barito Utara \\
\hline & $\begin{array}{l}\text { Local Reg. } \\
\text { 14/2011 }\end{array}$ & $\begin{array}{l}\text { Local Reg. } \\
3 / 2019\end{array}$ & $\begin{array}{l}\text { Local Reg. } \\
11 / 2017\end{array}$ & Local Reg. 1/2019 \\
\hline \multicolumn{5}{|l|}{$\begin{array}{l}\text { Wildlife/ species } \\
\text { education }\end{array}$} \\
\hline $\begin{array}{l}\left.\text { Note: }{ }^{*}\right) \text { idea to er } \\
\text { refugee zone and }\end{array}$ & $\begin{array}{l}\text { ice legal st } \\
\text { ngrove area }\end{array}$ & of forest $\mathrm{fr}$ & protected $f$ & national park. ${ }^{* \star}$ ) species \\
\hline
\end{tabular}

\section{Discussion}

The comparison of these two documents shows slightly different results. Out of 14 indicators, the spatial plan of Semarang City fulfills 6, while only 4 are found in the spatial Plan of Barito Utara Regency.

Semarang City Government has integrated more multispecies ideas into its spatial plan, which is integrated into the allocation of land for urban forest (70 hectares), city parks (2189 hectares), and various types of green barriers including greenbelt of the coast (250 hectares), rivers (641 hectares), dams and ponds (122 hectares), high electricity transmission corridors (60 hectares), railways (38 hectares), and graveyards (89 hectares). These are locally known as public green open spaces.

Graveyard is one of the elements of urban green space identified in the Semarang spatial plan. Traditional graveyards in Indonesia have an important role in the context of multispecies as they are sacred place, and the local authority has minimum intervention and let the area grow naturally. However, it is difficult to categorize graveyard in the existing framework of multispecies planning indicators. Additionally, analog habitat and private green open space with total of 3737 hectares are also highlighted in the spatial plan of the city. Urban wildlife management is also articulated in the spatial plan of Semarang as species refugee and mangrove areas.

Meanwhile, the spatial plan of Barito Utara Regency allocates land for protected forest (35,687 hectares) and two natural reserves (5952 hectares), known as Pararawen I and II. It is Barito Utara's advantage over Semarang. Semarang does not have protected forests and natural reserves, as does Barito Utara Regency. They both have different ecological assets. 
Unfortunately, other multispecies indicators in the form of public green open space, such as forests and city parks have not been allocated in Barito Utara. Although it is not stated in the RTRW of Barito Utara Regency, these parameters are expected to be fulfilled because the Medium-Term Regional Development Plan (RPJMD) of Barito Utara Regency states that there is a green open space management program. It can be seen also for the private green open space component that has not been regulated in the spatial plan. In addition, indicators for urban wildlife management have been overlooked in the spatial plan of Barito Utara.

The allocation of space for green barrier is shown in both case studies. However, the types of green barrier in Semarang spatial plan are more varies than that in Barito Utara. Spatial plan of Barito Utara only identifies green belt of river, tributary, and dam or lake. Medium-Term Regional Development Plan (RPJMD) of the Barito Utara Regency states that there is a replantation program on the riverbank, lake, water catchment and spring which could support the idea of multispecies urban planning.

There are five indicators that have not been integrated in the spatial plan of both case studies namely the indicators for ecological corridors, botanical gardens, vacant lands, abandon areas, and education on wildlife and species. In the context of spatial connectivity, the two regions do not plan an ecological corridor. The Kalimantan Island Spatial Plan actually has given mandate to the national government to link natural reserve of Pararawen I and Pararawen II by an ecological corridor. Unfortunately, changes in the national spatial plan led to the elimination of the ecological corridor plan.

Briefly, the city of Semarang which has lower biodiversity assets when compared to Barito Utara has more detailed articles addressing multispecies urban planning indicators. Furthermore, the city of Semarang has indicated the importance of urban ecological study and wildlife habitats as a basis for urban wildlife management. Unfortunately, there is no similar indication in Barito Utara Regency. In fact, urban ecological study is important for enriching environmental information systems for planners as it has been practiced for a long time in the UK (Culshaw et al, 2006) known as The Environmental Information System for Planners (EISP), is a concept web-based system designed to support decision making within the UK planning framework by making information on environmental issues more widely accessible.

\section{Conclusion}

Combining the analysis at the national and local, this study underlines two important conclusions. First, regulatory frameworks at the national level does not really determine multispecies urban planning practices at the local level. In the Indonesian context, imperfect regulatory framework cannot be justified as an excuse to hinder the integration of multispecies perspective in the practice of urban planning. Most of the indicators for multispecies urban planning are contained in the regulatory framework, both in the spatial planning and sectoral domains with all its advantages and disadvantages. Therefore, there is no reason for urban planners at the local level to procrastinate translating national regulatory frameworks into multispecies urban planning practice. However, this study still underlines that regulation on 
ecological corridor need to be strengthened. Whilst, urban wildlife management, management of abandoned areas and analog habitat which are not yet included at the national regulatory frameworks need to be paid attention. City governments must have the courage to integrate multispecies perspectives into spatial plan and practices amid imperfect national regulatory frameworks.

Second, the status of biodiversity owned by a city does not affect its planning practice. Having a greater biodiversity does not always inspire city planners and the planning commission to integrate a multispecies perspective in the spatial plan and design. The richness of biological diversity in a region also does not encourage urban planners to translate existing regulatory frameworks into multispeciessensitive spatial plan and practice. It is proven that variations of multispecies planning indicator are more often found in Semarang than Barito Utara. At this level, we think that human actors such as planners, planning committee, and other key decision makers who have adequate literacy on multispecies planning, play an important role. This warrants a further investigation.

\section{Declarations}

The authors acknowledge the support of Diponegoro University which provide funding to the research through Hibah Bersaing Dana RKAT Fakultas Teknik 2020. The authors confirm that there is no conflict of interest resulted from the research.

\section{Availability of data and material:}

The research employs secondary public data that can be accessed by anyone.

\section{Code availability:}

Not relevant

\section{Authors' contribution:}

Not relevant

\section{Ethics approval:}

Not relevant/ waivers

\section{Consent to participate:}

Not relevant 


\section{References}

1. Adams, L. W. (2005). Urban wildlife ecology and conservation: A brief history of the discipline. Urban Ecosystems. https://doi.org/10.1007/s11252-005-4377-7

2. Afif, J., Ngabekti, S., \& Pribadi, T. A. (2014). Keanekaragaman makrozoobentos sebagai indikator kualitas perairan di ekosistem mangrove wilayah tapak kelurahan Tugurejo Kota Semarang. Retrieved from http://journal.unnes.ac.id

3. Almenar, J. B., Bolowich, A., Elliot, T., Geneletti, D., Sonnemann, G., \& Rugani, B. (2019). Assessing habitat loss, fragmentation and ecological connectivity in Luxembourg to support spatial planning. Landscape and Urban Planning. https://doi.org/10.1016/j.landurbplan.2019.05.004

4. Aminipouri, M., Rayner, D., Lindberg, F., Thorsson, S., Knudby, A. J., Zickfeld, K., Krayenhoff, E. S. (2019). Urban tree planting to maintain outdoor thermal comfort under climate change: The case of Vancouver's local climate zones. Building and Environment.

https://doi.org/10.1016/j.buildenv.2019.05.022

5. Anderson, P., Charles-Dominique, T., Ernstson, H., Andersson, E., Goodness, J., \& Elmqvist, T. (2020). Post-apartheid ecologies in the City of Cape Town: An examination of plant functional traits in relation to urban gradients. Landscape and Urban Planning.

https://doi.org/10.1016/j.landurbplan.2019.103662

6. Atlanta City Government. (2015). City of Atlanta Climate Action Plan: Local Actions and Policies for Reducing City of Atlanta's Greenhouse Gas Emissions, City of Atlanta Mayor's Office of Sustainability. Retrieved from https://atlantaclimateactionplan.files.wordpress.com

7. Atlanta City Government. (2020). Nature: A Plan to Protect, Restore and Accentuate Urban Ecology of Atlanta, Department of City Planning, https://www.atlantaga.gov/home/showdocument?id=48625

8. Bateman, P. W., \& Fleming, P. A. (2012). Big city life: Carnivores in urban environments. Journal of Zoology. https://doi.org/10.1111/j.1469-7998.2011.00887.x

9. Bengis, R.G., Leighton, F.A., Fischer, J.R., Artois, M., Mörner, T., Tate, C.M. (2004). The role of wildlife in emerging and re-emerging zoonoses. Revue scientifique et technique (International Office of Epizootics). DOI: 10.20506/rst.23.2.1498

10. Borgström, S., Lindborg, R., Elmqvist, T. (2013). Nature conservation for what? Analyses of urban and rural nature reserves in southern Sweden 1909-2006. Landscape and Urban Planning, 117, 66-80. http://dx.doi.org/10.1016/j.landurbplan.2013.04.010

11. Bush, J \& Doyon, A. (2019). Building urban resilience with nature-based solutions: How can urban planning contribute? Cities, 95, 102483. https://doi.org/10.1016/j.cities.2019.102483

12. Byrne, J., \& Wolch, J. (2009). Urban Habitats/Nature. International Encyclopedia of Human Geography. https://doi.org/10.1016/B978-008044910-4.01091-9

13. Cardoso, M. C., \& Gonçalves, R. B. (2018). Reduction by half: the impact on bees of 34 years of urbanization. Urban Ecosystems. https://doi.org/10.1007/s11252-018-0773-7 
14. Cavanagh, J. F., Cohen, M. X., \& Allen, J. J. B. (2009). Prelude to and resolution of an error: EEG phase synchrony reveals cognitive control dynamics during action monitoring. Journal of Neuroscience. https://doi.org/10.1523/JNEUROSCI.4137-08.2009

15. Clauzel, C., Jeliazkov, A., \& Mimet, A. (2018). Coupling a landscape-based approach and graph theory to maximize multispecific connectivity in bird communities. Landscape and Urban Planning. https://doi.org/10.1016/j.landurbplan.2018.07.002

16. Culshaw, M.G., Nathanail, C.P., Leeks, G.J.L., Alker, S., Bridge, D., Duffy, T., Fowler, D., Packman, J.C., Swetnam, R., Wadsworth, R., Wyatt, B. (2006). The role of web-based environmental information in urban planning-the environmental information system for planners. Science of the Total Environment, 360, 233-245. doi:10.1016/j.scitotenv.2005.08.037

17. Fischer C., Reperant L.A., Weber J.M., Hegglin D., \& Deplazes, P. (2005). Echinococcus Multilocularis infections of rural, residential and urban foxes (vulpes vulpes) in the canton of Geneva, Switzerland. Parasite, 2005, 12, 339-346. http://dx.doi.org/10.1051/parasite/2005124339

18. Flies, E.J., Skelly, C., Lovell, R., Breed, M.F., Phillips, D., Weinstein, P. (2018). Cities, biodiversity and health: we need healthy urban microbiome initiatives. Cities and Health, https://doi.org/10.1080/23748834.2018.1546641

19. Gkritza, K., Souleyrette, R., Baird, M., Danielson, B. (2014). An empirical bayes approach for estimating urban deer vehicle crashes using police and maintenance records. ASCE Journal of Transportation Engineering, 140 (2), 04013002. DOI: 10.1061/(ASCE)TE.1943-5436.0000629

20. Hardion, L., Barthélémyc, C., Consalesd, J., Gauthiere, P., Thompsone, J.D., Verlaqueb, R., Vila, B. (2015). An endangered reed, Arundo donaciformis, in a dynamic urban environment: The need for interdisciplinary conservation proposals. Journal for Nature Conservation, 26, 20-27. http://dx.doi.org/10.1016/j.jnc.2015.03.008

21. Hartigan, J. (2015). Plant Publics: Multispecies Relating in Spanish Botanical Garden. Anthropological Quarterly. https://doi.org/ 10.1353/anq.2015.0024

22. Houston, D., Maccallum, D., Steel, W., \& Byrne, J. (2017). Make kin, not cities! Multispecies entanglements and 'becoming-world' in planning theory. Planning Theory, https://doi.org/10.1177/1473095216688042

23. Hunold, C \& Lloro, T. (2019). There goes the neighborhood: urban coyotes and the politics of wildlife. Journal of Urban Affairs, https://doi.org/10.1080/07352166.2019.1680243

24. Karanth, K. K., Surendra, A. (2018). Species and sites matter: Understanding human-wildlife interactions from 5000 surveys in India. In Bhagwat, S. A. (Ed.), Conservation and Development in India (pp. 61-82). Routledge: Abindgon, UK: Routledge.

25. Kowarik, I. (2011). Novel urban ecosystems, biodiversity, and conservation. Environmental Pollution. 159, 1974-1983. doi:10.1016/j.envpol.2011.02.022

26. LaMontagne, J. M., Kilgour, R. J., Anderson, E. C., \& Magle, S. (2014). Tree cavity availability across forest, park, and residential habitats in a highly urban area. Urban Ecosystems. https://doi.org/10.1007/s11252-014-0383-y 
27. Leroy, E. M., Epelboin, A., Mondonge, V., Pourrut, X., Gonzalez, J. P., Muyembe-Tamfum, J. J., \& Formenty, P. (2009). Human Ebola outbreak resulting from direct exposure to fruit bats in Luebo, Democratic Republic of Congo, 2007. Vector Borne and Zoonotic Diseases (Larchmont, N. Y.), 9(6), 723-728. https://doi.org/10.1089/vbz.2008.0167

28. Lemey, P., Pybus, O. G., Wang, B., Saksena, N. K., Salemi, M., \& Vandamme, A. M. (2003). Tracing the origin and history of the HIV-2 epidemic. Proceedings of the National Academy of Sciences of the United States of America, 100(11), 6588-6592. https://doi.org/10.1073/pnas. 0936469100

29. Magama, Y.A., Babagana, M., Usman, A.U., Gujja, A.A., Adamu, A., Karachi, A.E. (2018). Assessment of Wildlife Species Mostly Involved in Human-Wildlife Conflict around Yankari Game Reserve, Bauchi State, Nigeria, International Journal of Contemporary Research and Review, 9(9), 2026220277. https://doi.org/10.15520/ijcrr/2018/9/09/605

30. McDonald, R. I. (2015). Conservation For Cities: How to Plan and Build Natural Infrastructure. Urban Planning. Washington, DC: Island Press.

31. Mendez, D. H., Judd, J., \& Speare, R. (2012). Unexpected Result of Hendra Virus Outbreaks for Veterinarians, Queensland, Australia. Emerging Infectious Diseases, 18(1), 83-

85. https://dx.doi.org/10.3201/eid1801.111006

32. Messmer, T. A. (2000). The emergence of human-wildlife conflict management: turning challenges into opportunities. International Biodeterioration \& Biodegradation. https://doi.org/10.1016/j.rbre.2015.08.008

33. Ogden, L.A., Hall, B., Tanita, K., 2013. Animals, Plants, People, and Things: A Review of Multispecies Ethnography. Environment and Society. 4, 5-24.

https://doi.org/10.3167/ares.2013.040102

34. Olive, A \& Minichiello, A. (2013). Wild things in urban places: America's largest cities and multi-scales of governance for endangered species conservation, Applied Geography. 43, 56-66. http://dx.doi.org/10.1016/j.apgeog.2013.06.004

35. Parris, K. M., Amati, M., Bekessy, S. A., Dagenais, D., Fryd, O., Hahs, A. K., Williams, N. S. G. (2018). The seven lamps of planning for biodiversity in the city. Cities. 83, 44-53. https://doi.org/10.1016/j.cities.2018.06.007

36. Plumwood, V. (2009). Nature in the Active Voice. Australian Humanities Review. https://doi.org/10.22459/AHR.46.2009.10

37. Poessel, S. A., Gese, E. M., \& Young, J. K. (2017). Environmental factors influencing the occurrence of coyotes and conflicts in urban areas. Landscape and Urban Planning. https://doi.org/10.1016/j.landurbplan.2016.05.022

38. Rall, E.L., Kabisch, N., \& Hansen, R. (2015). A comparative exploration of uptake and potential application of ecosystem services in urban planning. Ecosystem Services. 16, 230-242. http://dx.doi.org/10.1016/j.ecoser.2015.10.005

39. Rodríguez-Rodríguez, D \& Martínez-Vega, J. (2018). Protected area effectiveness against land development in Spain. Journal of Environmental Management. 215, 345-357. 
40. Rupprecht, C. D. D. (2017). Ready for more-Than-human? Measuring urban residents' willingness to coexist with animals. Fennia. https://doi.org/10.11143/fennia.64182

41. Shapiro, K., Miller, M., \& Mazet, J. (2012). Temporal association between land-based runoff events and California sea otter (Enhydra lutris nereis) protozoal mortalities. Journal of Wildlife Diseases, 48(2), 394-404. https://doi.org/10.7589/0090-3558-48.2.394

42. Schmidt, K. J., Poppendieck, H. H., \& Jensen, K. (2014). Effects of urban structure on plant species richness in a large European city. Urban Ecosystems. https://doi.org/10.1007/s11252-013-0319-y

43. Sharp, P. M., Bailes, E., Gao, F., Beer, B. E., Hirsch, V. M., \& Hahn, B. H. (2000). Origins and evolution of AIDS viruses: estimating the time-scale. Biochemical Society Transactions, 28(2), 275282. https://doi.org/10.1042/bst0280275

44. Smith, I., \& Wang, L. F. (2013). Bats and their virome: an important source of emerging viruses capable of infecting humans. Current Opinion in Virology, 3(1), 8491. https://doi.org/10.1016/j.coviro.2012.11.006

45. Soulsbury, C. D., \& White, P. C. L. (2015). Human-wildlife interactions in urban areas: A review of conflicts, benefits and opportunities. Wildlife Research. https://doi.org/10.1071/WR14229

46. Spash, C. L., Urama, K., Burton, R., Kenyon, W., Shannon, P., \& Hill, G. (2009). Motives behind willingness to pay for improving biodiversity in a water ecosystem: Economics, ethics and social psychology. Ecological Economics. https://doi.org/10.1016/j.ecolecon.2006.09.013

47. Steele, W., Wiesel, I., \& Maller, C. (2019). Geoforum More-than-human cities: Where the wild things are? Geoforum. https://doi.org/10.1016/j.geoforum.2019.04.007

48. Subekti, N. (2012). Keanekaragaman Jenis Serangga di Hutan Tinjomoyo Kota Semarang, Jawa Tengah (Insect Diversity of Tinjomoyo Forest Semarang City, Central Java). Jurnal Tengkawang. http://dx.doi.org/10.26418/jt.v2i1.1636

49. Suwarso, E., Paulus, D. R., \& Widanirmala, M. (2019). Kajian Database Keanekaragaman Hayati Kota Semarang. Jurnal Riptek. Retrieved from https://riptek.semarangkota.go.id

50. United Nations. (2008). Spatial Planning - Key Instrument for Development and Effective Governance with Special Reference to Countries in Transition. Economic Commission for Europe. https://doi.org/ECE/HBP/146

51. United Nations (Habitat III). (2017). New Urban Agenda. Retrieved from www.habitat3.org

52. van Dooren, T, \& Rose, D. B. (2012). Storied-places in a multispecies city. Humanimalia. Retrieved from https://www.depauw.edu

53. van Dooren, T., Kirksey, E., Münster, U. (2016). Multispecies Studies: Cultivating Arts of Attentiveness. Environmental Humanities. 8, 1-23. https://doi.org/10.1215/22011919-3527695

54. Vecchio, A., Marzluf, D., \& Fitzgerald, P. (2019). National Wildlife Week: Top 10 Cities for Wildlife. Retrieved from https://blog.nwf.org/2019/03/national-wildlife-week-top-10-cities-for-wildlife/

55. Wang, Y., \& Akbari, H. (2016). The effects of street tree planting on Urban Heat Island mitigation in Montreal. Sustainable Cities and Society. https://doi.org/10.1016/j.scs.2016.04.013 
56. Wang, Y., \& Zacharias, J. (2015). Landscape modification for ambient environmental improvement in central business districts - A case from Beijing. Urban Forestry and Urban Greening. https://doi.org/10.1016/j.ufug.2014.11.005

57. Wolch, J. (2002). Anima urbis. Progress in Human Geography. https://doi.org/10.1191/0309132502ph400oa

58. World Health Organization: Summary table of SARS cases by country, 1 November 2002- 7 August 2003. https://www.who.int/csr/sars/country/table2003_09_23/en/

59. Zwierzchowska, I., Fagiewicz, K., Poniży, L., Lupa, P., Mizgajski, A. (2019). Introducing nature-based solutions into urban policy - facts and gaps. Case T study of Poznań. Land Use Policy. 85, 161-175. https://doi.org/10.1016/j.landusepol.2019.03.025

\section{Figures}

\section{MAP OF INDONESIA}

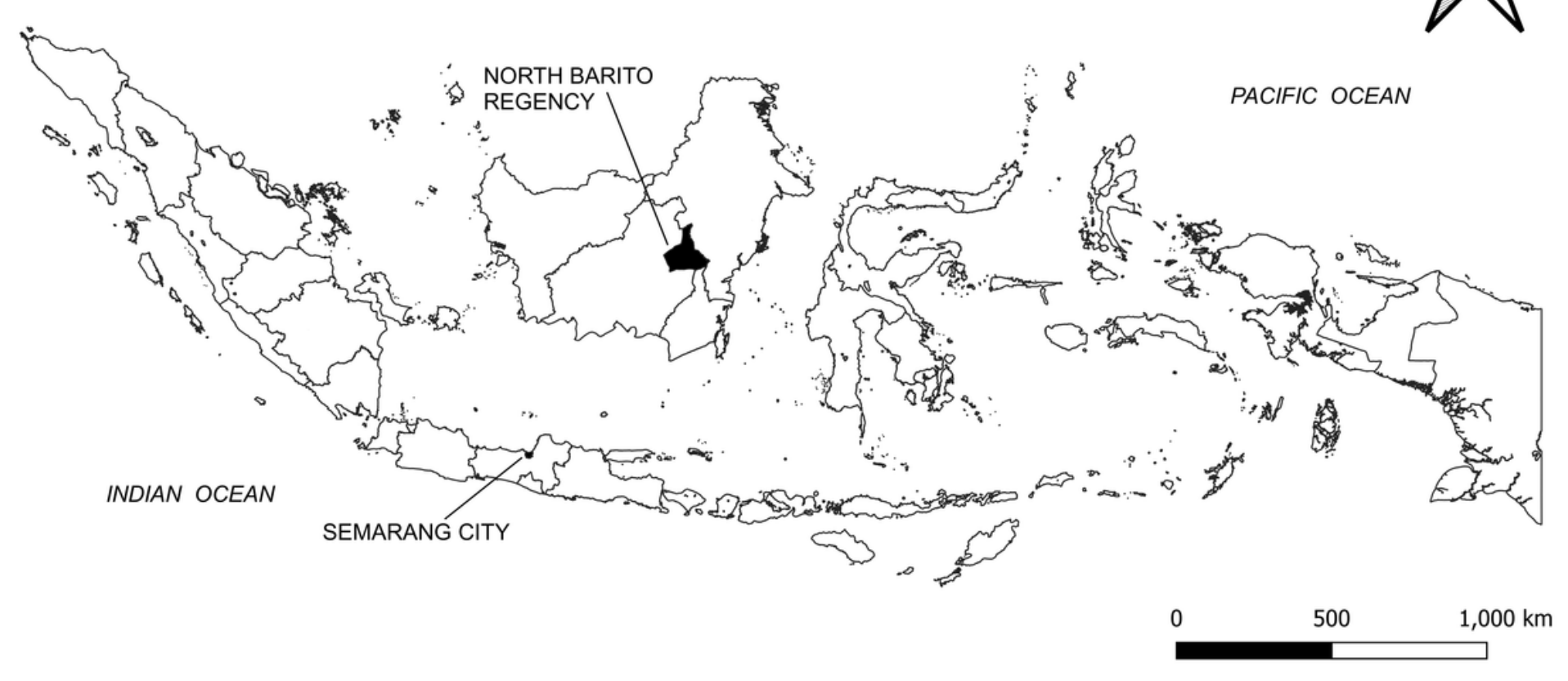

\section{Figure 1}

Study Area 


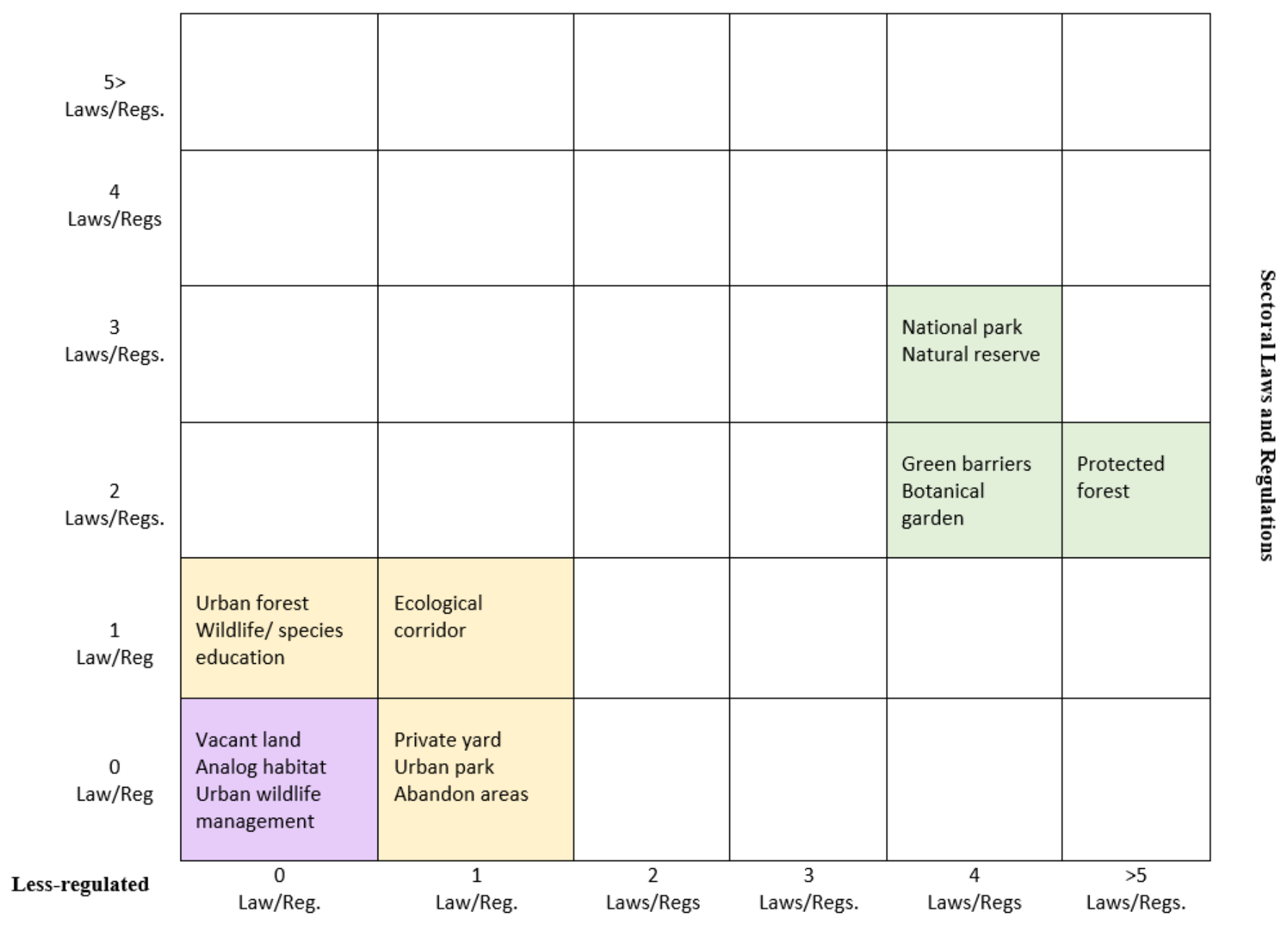

Figure 2

Relative Emphasis of Multispecies Urban Planning Indicators based on Indonesian Regulatory Framework 